\title{
Scope Extension that Forms the Secondary Meaning in Legal Terminology
}

\author{
Lidiia V. Vlasova* \\ St. Petersburg State University of Economics \\ 21 Sadovaya Str., St. Petersburg, 191023, Russia
}

Received 03.03.2018, received in revised form 16.04.2018, accepted 27.04.2018

\begin{abstract}
The article addresses the ways of the secondary meaning formation in legal terminology - with particular focus to scope extension. This method is less common in comparison with metaphors, metonymies or scope narrowing that is explained by the legal term's aim to achieve monosemy in its notion within the targeted term system. The main factors contributing to the secondary scope extension are certain types of metonymic shifts (e.g. "cause - effect") and semantic ambiguity as well.
\end{abstract}

Keywords: secondary meaning, scope extension, legal terminology, legal discourse, legal term system.

DOI: 10.17516/1997-1370-0276.

Research area: linguistics.

At this moment legal terminology is an essential part of language's term system that is explained, firstly, by a great importance of the law in contemporary life and businesses; secondly, by a wide range of its applications as compared with other terminologies: the legal one can be used both in specific and in everyday communication. The obvious question to ask is: what the legal terminology is? It means a set of unified legal terms used in the legislation. The legal term, in turn, is a word used in the legislation which represents a generalized name for the legal notion with exact meaning; the legal term is characterized by semantic ambiguity and functional strength (Zemlianaia et al., 2010). Legal terms are used to formulate legal instructions more accurately and to achieve that maximum brevity in legal texts. These terms constitute a base for prescriptive texts and forms its content ground. They function within the legal discourse - a result of individual cognitive activity in the sphere of law. The main feature of legal terms as a means of professional communication is their close reference with the world view and ideology of the authorities with different political and legal theories, scientific movements and legal experience (Khizhniak, 1997: 57). Still, how can we decide whether the term is originally legal or not? To deal this issue, there are several classifications of criteria placed on legal terms. Among them, the one developed by I.N. Bokova is considered to be the most universal and general (Bokova, 2002: 81). It includes three types of requirements: 1 . Legal requirements (compliance with the terms and conditions of legal methodology); 2. Logics (compliance with logical laws and principles);

(C) Siberian Federal University. All rights reserved

* Corresponding author E-mail address: lida.vlasova.86@mail.ru 
3. Grammar (compliance with lexical, spelling and syntactic norms). This classification can be applied to the notion systems in all legal branches since these requirements are interconnected they are all of the same nature. Thus, in sum, the legal term shall meet the following demands: 1) monosemy; 2) accuracy; 3) lack of emotional, expressive or modal functions; 4) neutral style; 5) consistency; 6) brevity (dominance either oneword or two-words terms).

Such intrinsic features of the legal term as its commitment to accuracy and monosemy may contradict some common language universals, e.g. linguistic economy, leading to semantic ambiguity resulted from sign-diffuseness. Before turning to the term "semantic diffuseness" it is necessary to consider the term "linguistic ambiguity" as a resource for semantic diffuseness. Linguistic ambiguity means the existence of several meanings in the corpus (text) (Zalizniak, 2006: 17). Semantic diffuseness is "semantic underdefiniteness of different language signs (morphemes, lexical items, word combinations, sentences and texts), blurred borders between meanings and their categories in the semantic system and linguistic communication" (Kiklewicz, 2007: 302). Semantic diffuseness is included into the area of semantic ambiguity giving a rise to polysemy and enantiosemy, thus, setting a cross-disciplinary tone to the terms. In such a way, the legal terminology is formed under two diverse tendencies: inside the language they actualize such features as diffuseness and pursue of linguistic economy, while inside the legal term system - brevity and accuracy.

The impact of these two tendencies results in secondary meanings in the legal terms. The most commonly encountered ways of the secondary meaning formation are metaphor, metonymy, narrowing and extension of the meaning (scope). Metaphor can be analyzed through three different perspectives: 1 . In stylistics metaphor means a stylistic device based on similarities of features between two notions; 2. In semantics, metaphor realizes two meanings: nominative and derived; 3. In semiotics and cognitology, metaphor is a universal structure of the human thinking which allows comparing phenomena and facts to identify similarities and differences (Arutyunova, 1999: 107). In the legal terms, the formation of secondary meaning involves the following types of metaphors: generalizing, nominative, comparative and cognitive ones. It is worth noting, that metaphorization and metonymyzation are widely represented in the formation of secondary meaning not only in the legal terms, but also in other terms in different languages for special purposes. There may be such cases where metonymic shift enhances the secondary meaning's volume, especially, given the following conceptual relations between the interacting categories: 1. Place - population, event; 2. Action - result, place; 3. Event participants; 4. Institution - employees; 5. Author - work; 6. Synecdoche; cause - effect.

We'll see the examples of how the secondary meaning is formed through the scope extension exemplified by the common legal terms and specific terminology in the Criminal Code of the French Republic (as amended and supplemented at January 1, 2002) in French (http://www. legifrance.gouv.fr/) and English (http://www. legifrance.gouv.fr/Traductions/en-English). Yet, it should be taken into consideration that the content of legal terms and notions can vary depending on the legal system: the French one operates under the Romano-Germanic legal family while the English - under the AngloSaxon framework (Saidov, 2007: 200). When considering these terms, there is an atypical situation: the legal terms fixed in the RomanoGermanic legal family (primary legal family) are expressed formally through the legal terms of the Anglo-Saxon legal family (secondary 
legal family) that supports intensification of semantic ambiguity in the primary legal terms by the means of the secondary legal family due to different legal realia inside the legal families.

Let's further address the secondary meaning formation through the scope extension on the example of common legal terms and specific terminology in the French language. The scope extension comes from: 1 . Shift from the common lexis into the common legal terminology (derived meaning of "violence" - "contempt" (formed from the basic meaning "violence" "behaviour involving physical force intended to hurt of damage smb/smth"); derived meaning of "défaut" - "absence" (formed from the basic meaning - "défaut" - "defect"); derived meanings of "procédure" - "legal procedure, trial" (formed from the basic meaning - "procédure" "procedure, proceedings"); derived meaning of "homicide" - "murder" (formed from the basic meaning "homicide" - "deadly"); 2. Shift from the specific legal terminology (i.e. the term's meaning is relevant only for a particular legal area) into the common legal terminology (derived meaning in "délit" - "criminal activity" (formed from the basic meaning "délit" - "civil injury"); derived meaning of "lésion" - "damage, killing, trauma" (formed from "bodily injury"); derived meaning of "délaissement" - "neglecting" (formed from "délaissement" - "abandonment"); derived meaning of "enlèvement" - "exclusion" (formed from the basic meaning "enlèvement" "seizure, deletion"); derived meaning of "recel" - "withholding" (formed from the basic meaning "recel" - "receiving"); derived meaning of "condamnation" - "record of criminal conviction" (formed from the basic meaning "condamnation" - "condemnation in criminal procedure"); 3. Metonymic shift ("action - result"): "contravention" - "protocol on violation" (formed from "incongruity, contempt"); "annulation" _ "invalidation" (formed from "cancellation, disaffirmance"); "contûmace" - "trial in absentia" (formed from "failure to attend court proceeding (by the panel/ defendant)"; "dégradation" - "loss of some rights" (formed from the basic meaning "wrong-doing, damaging"); "titulaire" - "a person entitled to the right" (formed from "a person with permanent employment"); "cause - effect": "gravité" "degree" (formed from "severity/gravity"); "receleur" - "a person receiving offender" (formed from the basic meaning "a fence for stolen goods"); synecdoche: "ministè republic" - "prosecutor" (formed from the basic meaning "prosecution office"); "protocole" - "protocol section" (formed from the basic meaning "minutes/protocol"); "autorité" - "public authority" (formed from the basic meaning "authority/power"); "action place": "enregistrement" - "registry office" (formed from the basic meaning "registration/ listing"). The lexico-semantic analysis has not shown such French legal terms the secondary meaning of which would be derived through such metonymic shifts as "place - event", "action participant", "institution - employee" or "work author". Among the metonymic shifts under our consideration "action - result" and "cause effect" shifts have been mostly found.

We will also take the secondary meaning formation through the scope extension using the example of the English common and specific legal terms. Here also, the scope extension can be caused by: 1 . Shift from common lexis into common legal terminology (derived meaning in "violence" - "contempt" (formed from the basic meaning "violence" - "behaviour involving physical force intended to hurt of damage smb/smth"); "safety" - "safe-keeping" (formed from the basic meaning "security"); 2. Shift from specific legal terminology into common legal terminology ("imprisonment" "deprivation of freedom" (formed from the basic meaning "confinement"); "peremption" - 
"cancellation, disaffirmance" (formed from the basic meaning "dismissal of case by virtue of failing to file essential evidences"); "penalty" - "punitive measure" (formed from the basic meaning "collection/fine"); "examination" - "advisement" (formed from the basic meaning "examination/having"); "restraint" - "interdiction" (formed from the basic meaning "restriction/imprisonment"); 3. Metonymic shifts - "action - result": "crime" "criminality" (formed from the basic meaning "misdeed/wrong-doing"); "review" - "study/ description" (formed from the basic meaning "retrial/redetermination"); "parole" - "release on parole" (formed from the basic meaning "promise"); "defacement" - "disfigurement" (formed from the basic meaning "damage/ spoiling"); "contempt" - "violation" (formed from the basic meaning "disrespectful attitude/ offence"); "liability" - "obligation" (formed from the basic meaning "responsibility"); "cause - effect": "gravity" - "degree" (formed from the basic meaning "severity/gravity"); "transmission" - "conductive document" (formed from the secondary meaning "further passing"); "receiver" - "tax collector" (formed from the basic meaning "recipient"); synecdoche: "authority" - "public authority" (formed from the basic meaning "authority/ power"); "office" - "agency/bureau" (formed from the secondary meaning "department/ institution"); "law" - "act/legislation" (formed from the basic meaning "right"); "action place": "impounding" - "demurrage penalty" (formed from the basic meaning "demurrage"); "mission" - "assignment/business trip" (formed from the basic meaning "mission/delegation"); "criminal record" - "a history of being convicted for crime" (formed from the basic meaning "criminal file"); "protection" - "passport/ certificate of citizenship" (formed from the basic meaning "defence/security"); "work - author": "witness" - "statement of evidence" (formed from the basic meaning "witness/attestor"). Considering the English legal terms within the lexico-semantic context, we have found no unities which would be originated through such metonymic shifts as "place - event", "event participant" or "institution - participant". Still, the most common types of them are "action result" and "cause - effect".

Thus, among the applied types of metonymic shifts in the secondary meaning formation both in the French and the English legal terms, "action result" and "cause - effect" ones appears to be the most frequent. Such situation may be explained through a number of reasons: by prescriptive nature of the law and clear cause-effect relations between criminal actions and corresponding penalties.

Summing up, it worth nothing that the scope extension as a manner of the secondary meaning production in the legal terminology is less commonly used than metaphors, metonymies or scope narrowing, since the legal term aims for the notion's monosemy within the term system. In such a way, the most typical devices for the secondary meaning formation in the legal area are scope narrowing and metonymy owing to the human cognition's features and the term's drive for achieving particular meaning in its notion.

\section{References}

Arutyunova, N.D. (1999). Iazyk i mir cheloveka [The Human's Language and World]. Moscow, Iazyki russkoi kul'tury, 896 p.

Bokova, I.N. (2002). Iuridicheskaya tekhnika v ugolovnom prave: kachestvo zakona i zakonotvorcheskaya oshibka [Legal Methodoly in Criminal Law: Law Quality and Mistakes in Law 
Making Procedures], In Nauchnye trudy RAYUN, T.1 [Scientific Papers of the Russian Academy of Legal Sciences, vol. 1]. Moscow, Iurist, 379 p.

Khizhniak, S.P.(1997).Anglo-amerikanskayairusskayaterminologiiaprava:sotsiolingvisticheskii aspekt vozniknoveniia i razvitiia [English-American and Russian Legal Terminology: Socio-linguistic Aspect of Its Origin and Development]. Saratov, SGAP, 212 p.

Kiklewicz, A. (2007). Zrozumiec jezyk. Sckicez filozofii jezyka, semanytki, lingiwistyki, komunikacyjnej. Lask, 374.

Saidov, A.H. (2007). Sravnitel'noe pravovedenie [Comparative Legal Studies]. Moscow, Norma, $368 \mathrm{p}$.

Ugolovnii kodeks Frantsii na angliiskom iazyke [The Criminal Code of the French Republic, in English], available at: http://www.legifrance.gouv.fr/Traductions/en-English

Ugolovnii kodeks Frantsii na frantsuzskom iazyke [The Criminal Code of the French Republic, in French], available at: http://www.legifrance.gouv.fr/

Zalizniak, A.A. (2006). Mnogoznachnost' v iazyke i sposoby eio predstavleniya [Linguistic Polysemy and Its Representation]. Moscow, Iazyki slavianskikh kul'tur, $672 \mathrm{p}$.

Zemlianaia, T.B., Pavlycheva, O.N. (2010). Klassifikatsiya iuridicheskikh terminov [Classification of Legal Terms], In Zhurnal nauchno-pedagogicheskoi informatsii [Journal of Scientific and Pedagogical Information], 7, available at: http://siberia.com/publ/satti/stati/o_edinstve_terminologii_ normativno_pravovykh_aktov_zemljanaja_t_b_pavlycheva_o_n/4-1-0-213

\section{Расширение объема значения}

как способ образования производного значения

в юридической терминологии

Л.В. Власова

Санкт-Петербургский государственный экономический университет

Россия, 191023, Санкт-Петербург, ул. Садовая, 21

В статье рассматриваются способы образования производного значения в юридической терминологии, в особенности расширение объема значения. Данный способ образования производного значения наименее распространен по сравнению с метафорой, метонимией и сужением объема значения, что вызвано стремлением юридического термина к однозначности выражаемого им понятия в пределах заданной терминосистемы. Основными факторами расширения объема производного значения являются некоторые виды метонимических переносов (например, метонимический перенос «причина - следствие»), а также семантическая неопределенность.

Ключевые слова: производное значение, расширение объема значения, юридическая терминология, юридический дискурс, юридическая терминосистема.

Научная специальность: 10.02.00 - лингвистика. 